\section{AUTHOR INDEX - VOLUME 36, 1994}

Allen, M. S. The Chronology of Coastal Morphogenesis and Human Settleinent on Aitutaki, Southern Cook Islands, Polynesia, 59

Ambers, J. British Museum Natural Radiocarbon Measurements XXIII, 95

An, Z. see Zhou, W., 37

Arnold, A. see Pazdur, A., 187

Arnold, J. R. Obituary-Hans E. Suess, xi(1)

Awsiuk, R. see Pazdur, M. F., 257

Baillie, M. G. L. see McCormac, F. G., 27

Berendsen, H. J. A. see Stolk, A., 1

Bhushan, R. Physical Research Laboratory (Chemistry) Radiocarbon Date List I, 251

Bierkens, M. F. B. see Törnqvist, T. E., 11

Bintz, P. see Evin, J., 345

Bonani, G. AMS ${ }^{14}$ C Age Determinations of Tissue, Bone and Grass Samples from the Ötztal Ice Man, 247

Bönisch, G. see Schlosser, P., 327

Bowman, S. see Ambers, J., 95

Bradley, L.-A. Comparison of Manual and Automated Pretreatment Methods for AMS Radiocarbon Dating of Plant Fossils, 399

Bronić, I. K. see Obelić, B., 303

Brown, D. M. see McCormac, F. G., 27

Calderoni, G. Department of Earth Sciences at the University of Rome Radiocarbon Dates II, 133; Department of Earth Sciences at the University of Rome Radiocarbon Dates III, 143

Caneva, I. see Calderoni, G., 143

Carmi, I. Dating the Prehistoric Site Nahal Issaron in the Southern Negev, Israel, 391

Cazzella, A. see Calderoni, G. 143

Chakraborty, S. see Bhushan, R., 251

Cole, T. R. L. see McFadgen, 221

Dabous, A. A. see Srdoc, D., 203

Dye, T. Apparent Ages of Marine Shells: Implications for Archaeological Dating in Hawai'i, 51

Ekwurzel, B. see Schlosser, P., 327

Evin, J. Human Settlements and the Last Deglaciation in the French Alps, 345

Frangipane, M. see Calderoni, G., 143

Fritz, P. Obituary-Jean-Charles Fontes, ix(1)

Gagnon, A. R. see McNichol, A. P., 237

Gonfiantini, R. see Fritz, P., ix(1)

Gopher, A. see Carmi, I., 391

Goring-Morris, A. N. see Carmi, I., 391

Goslar, T. see Pazdur, A., 187; Pazdur, M. F., 257

Grgić, S. see Obelić, B., 303

Hajdas, I. see Bonani, G., 247

Hall, V. A. see Richardson, F., 407
Head, M. J. ANU Radiocarbon Date List XI, 73; see also Zhou, W., 37, 47.

Hekhuis, K. P. V. see Stolk, A., 1

Hoper, S. T. see McCormac, F. G., 27

Horvatincić, N. see Srdoc, D., 203; Obelić, B., 303

Hutton, D. L. see McNichol, A. P., 237

Ivy, S. D. see Bonani, G., 247

Jones, G. A. see McNichol, A. P., 237

Jull, A. J. T. see Long, A., iii(2); Long, A., iii(3); see also Kuzmin, Y. V., 359

Kaihola, L. see Zhou, W., 47

Knox, F. B. see McFadgen, 221

Kra, R. S. see Long, A., iii(2); Long, A., iii(3)

Krishnaswami, S. see Bhushan, R., 251

Kromer, B. Obituary-Bernd Becker, iii(1); see also Schlosser, P., 327

Kuzmin, Y. V. Radiocarbon Dating of the Stone and Bronze Age Sites in Primorye (Russian Far East), 359; Prehistoric Colonization of Northeastern Siberia and Migration to America: Radiocarbon Evidence, 367

Liiva, A. Tartu Radiocarbon Dates XIII, 153

Liu, T.-K. National Taiwan University Radiocarbon Dates III, 113

Long, A. From the Editor, iii(1); From the Editors - To Our Friends, iii(2); From the Editors - To Our Friends (Continued), iii(3)

Loosli, H. H. Obituary-Ulrich Siegenthaler, v(3); see also Schlosser, P., 327

Loze, I. see Liiva, A., 153

McCormac, F. G. $\delta^{13}$ C From the Irish Oak Chronology, 27

McFadgen, B. G. Radiocarbon Calibration Curve Varia tions and Their Implications for the Interpretation of New Zealand Prehistory, 221

McNichol, A. P. The Rapid Preparation of Seawater $\mathrm{\Sigma CO}_{2}$ for Radiocarbon Analysis at the National Ocean Sciences AMS Facility, 237

Monjuvent, G. see Evin, J., 345

Niklaus, T. R. see Bonani, G., 247

Obelić, B. Rudjer Bošković Institute Radiocarbon Measurements XIII, 303; see also Srdoc, D., 203

Orlova, L. see Kuzmin, Y. V., 359

Osmond, J. K. see Srdoc, D., 203

Östlund, G. see Schlosser, P., 327

Pazdur, A. Radiocarbon Chronology of Late Glacial and Holocene Sedimentation and Water-level Changes in the Area of the Gosciqz Lake Basin, 187; Gliwice Radiocarbon Dates XII, 281; see also Pazdur, M. F., 257 
Pazdur, M. F. Gliwice Radiocarbon Dates XI, 257; see also Pazdur, A., 187; Pazdur, A., 281

Petrone, V. see Calderoni, G., 143

Pilcher, J. R. see McCormac, F. G., 27

Popov, S. G. see Zaitseva, G. I., 377

Purtschert, R. see Schlosser, P., 327

Richardson, F. Pollen Concentrate Preparation from Highly Organic Holocene Peat and Lake Deposits for AMS Dating, 407

Schlosser, P. On the ${ }^{14} \mathrm{C}$ and ${ }^{39} \mathrm{Ar}$ Distribution in the Central Arctic: Implications for Deep Water Formation, 327

Segal, D. see Carmi, I., 391

Sliep̌̌ević, A. see Obelić, B., 303

Srdoc, D. Radiocarbon and Uranium-Series Dating of the Plitvice Lakes Travertines, 203; see also Obelic, B., 303

Stafford, T. W., Jr. see Bradley, L.-A., 399

Stolk, A. Calibration of ${ }^{14} \mathrm{C}$ Histograms: A Comparison of Methods, 1
Sulerzhitsky, L. D. see Kuzmin, Y. V., 359

Suter, M. see Bonani, G., 247

Taylor, L. see Head, M. J., 73

Törnqvist, T. C. How Smooth Should Curves Be For Calibrating Radiocarbon Ages?, 11; see also Stolk, A., 1

van der Plicht, J. see Stolk, A. 1

Walanus, A. see Pazdur, M. F., 257

Walker, D. see Head, M. J., 73

Wicik, B. see Pazdur, A., 187

Zaitseva, G. I. Radiocarbon Dating Sites of Northwest Russia and Latvia, 377

Zale, R. ${ }^{14} \mathrm{C}$ Age Corrections in Antarctic Lake Sediments Inferred from Geochemistry, 173

Zastawny, A. see Pazdur, M. F., 257; Pazdur, A., 281

Zhou, W. Stratigraphic Division of Holocene Loess in China, 37; Small Sample Dating in China, 47

Zuppi, G. M. see Fritz, P., ix(1) 